\title{
Ethnic relations in contestation of Regional head election year 2010 in medan city
}

\author{
Edy Suhartono, Prof.Dr. Usman Pelly, Dr. Phil Ichwan Azhari \\ Master Programme at Anthropology Department \\ University of Medan State, UNIMED \\ Medan, North Sumatra \\ edy.suhartono@gmail.com
}

\begin{abstract}
This paper examines the issue of ethnicity relations with the Regional Head Election in Medan City on Mayor and Vice Mayor Election Year 2010.This research was conducted in Medan City by analyzing the result of Recapitulation of vote acquisition to candidate pairs who contest elections on 2 in each of 21 Subdistricts in Medan City. The method of writing is descriptive qualitative based on the analysis of the matrix of the vote in each candidate.The acquisition of data were collected by purposive sampling, combined with snowball sampling, especially on informants who will be interviewed from each sub-district by referring to the ethnic base. Furthermore, the secondary of data from the Recapitulation that has been Analyzed will be seen in conformity with the primaries of data from in-depth interviews to the informants and participant observation as well as the documentation of photo activities during the field. The conclusion is that at the Mayoral Election of 2010 round I, Rahudman- Eldin pair performed well with a vote of $51.72 \%$, Followed by the couple Sopyan Nelly in second with $48.28 \%$ of votes. In the second round, RahudmanEldin succeeded in getting $65.88 \%$ while the couple Sopyan Tan Nelly votes only get as much as $34.12 \%$.The victory of Rahudman Eldin gives clues to ethnic correlation. The figure of the couple Rahudman Eldin is a figure that represent Mandailings ethnic, Malay and Islam. This ethnic is almost spread in 21 sub-districts. The voice of support from any sub-districts to the couple Rahudman Eldin is represented the citizens of Medan City. Strong support for the couple Rahudman and Eldin, derived from many ethnic Including with the label of Islam. It has been made this pair relatively can be accepted by the citizens of Medan city. While the couple Sopyan Tan and Nelly somewhat difficult, to get support from people because the figure of SopyanTan and Nelly did not get fully support from the citizens of Medan city, especially from Moslem people.
\end{abstract}

Keywords: ethnic relations, contestation, general election

\section{INTRODUCTION}

Medan is the capital of North Sumatera with a population of 2,210,624 and an area of 265.00 $\mathrm{km} 2$ based on the statistical data 2015. The statistical data of Medan City consists of 21 districts, respectively are: District of Medan Barat, Medan Baru, Medan Timur, Medan Area, Medan Kota, Medan Polonia, Medan Petisah, Medan Johor, Medan Tuntungan, Medan Helvetia, Medan Sunggal, Medan Labuhan,

Medan Deli , Medan Belawan, Medan Tembung Marelan, Medan Maimun, Medan Selayang, Medan Denai, Medan Perjuangan, Medan Marelan, Medan Tuntungan

The Malays can be said as the host people or indigenous people who came at the first time. in this region. Then, followed by another tribes, like: Batak Minangkabau, Acehnese, Javanese, Chinese India Tamil, Sundanese, Arabic, Nias. ${ }^{1}$

[1] ${ }^{1}$ Pelly, Usman" Ethnicity: In Multicultural Politics, Book III, Casamesra Publisher, Medan, 2016
Portrait of multiethnic in this area is a real cultural and historically can not be denied. This fact should not be seen and interpreted as a negative thing and taboo in the Election process and will take place at some future time. Ethnic realities that exist in this area is a potential of social capital that can be used for private interests, including in the political contest that took place.

According to Bruner as quoted by Usman Pelly $(1994)^{2}$ there is no dominant culture in Medan City. All of ethnic have chracteristic and specific orientation. It can be seen through the pattern of settlement, occupation and ethnic group orientation.

Ethnic composition and percentage based on census 2010

\begin{tabular}{|r|l|l|c|c|}
\hline No & $\begin{array}{l}\text { Ethnni } \\
\text { c }\end{array}$ & $\begin{array}{l}\text { Amount of } \\
\text { people }\end{array}$ & Percentage & Rank \\
\hline 1 & Aceh & 4091451 & 1.73 & 14 \\
\hline 2 & Batak & $8,466,969$ & 3.58 & 3 \\
\hline
\end{tabular}

[2] 2 Pelly, Usman, Urbanization and Adaptation: The Role of Mission Minangkabau culture and Mandailings, LP3ES, Jakarta, 1994 


\begin{tabular}{|c|c|c|c|c|}
\hline 3 & Nias & $1,041,925$ & 0.44 & 30 \\
\hline 4 & Malay & $5,365,399$ & 2.27 & 9 \\
\hline 5 & $\begin{array}{l}\text { Minang } \\
\text { kabau }\end{array}$ & $6,462,713$ & 2.73 & 7 \\
\hline 6 & $\begin{array}{l}\text { Parts } \\
\text { from } \\
\text { Jambi }\end{array}$ & 1415547 & 0.6 & 25 \\
\hline 7 & $\begin{array}{l}\text { Tribe } \\
\text { from } \\
\text { South } \\
\text { Sumate } \\
\text { ra }\end{array}$ & $5,119,581$ & 2.16 & 10 \\
\hline 8 & $\begin{array}{l}\text { Tribes } \\
\text { from } \\
\text { Lampu } \\
\text { ng }\end{array}$ & 1.381 .660 & 0.58 & 26 \\
\hline 9 & $\begin{array}{l}\text { Parts } \\
\text { from } \\
\text { Sumatr } \\
\text { a Other }\end{array}$ & $2,204,472$ & 0.93 & 21 \\
\hline 10 & Betawi & $6,807,968$ & 2.88 & 6 \\
\hline 11 & $\begin{array}{l}\text { Tribe } \\
\text { from } \\
\text { Banten }\end{array}$ & $4,657,784$ & 1.97 & 11 \\
\hline 12 & Sunda & $36.701,670$ & 15.5 & 2 \\
\hline 13 & Java & $95,217,022$ & 40.22 & 1 \\
\hline 14 & Cirebon & $1,877,514$ & 0.79 & 24 \\
\hline 15 & Madura & $7,179,356$ & 3.03 & 5 \\
\hline 16 & Bali & $3,946,416$ & 1,87 & 15 \\
\hline 17 & Sasak & $3,173,127$ & 1.34 & 16 \\
\hline 18 & $\begin{array}{l}\text { Tribes } \\
\text { of West } \\
\text { Nusa } \\
\text { Tengga } \\
\text { ra } \\
\text { Other }\end{array}$ & $1,280,094$ & 0,54 & 27 \\
\hline 19 & 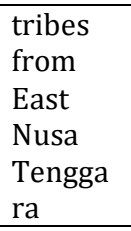 & $4,184,923$ & 1,77 & 12 \\
\hline 20 & Dayak & $3,009,494$ & 1,27 & 17 \\
\hline 21 & Banjar & $4,127,124$ & 1,74 & 13 \\
\hline 22 & $\begin{array}{l}\text { Tribes } \\
\text { of } \\
\text { Borneo } \\
\text { origin } \\
\text { other }\end{array}$ & 1.968620 & 0,83 & 22 \\
\hline 23 & $\begin{array}{l}\text { Makass } \\
\text { ar }\end{array}$ & $2.672,590$ & 1,13 & 20 \\
\hline 24 & Bugis & $6.359,700$ & 2,69 & 8 \\
\hline 25 & $\begin{array}{l}\text { Minaha } \\
\text { sa }\end{array}$ & $1,237,177$ & 0,52 & 29 \\
\hline 26 & $\begin{array}{l}\text { Goront } \\
\text { alo }\end{array}$ & $1,251,494$ & 0,53 & 28 \\
\hline 27 & $\begin{array}{l}\text { Tribe } \\
\text { from } \\
\text { Sulawe } \\
\text { si Other }\end{array}$ & $7,634,262$ & 3,22 & 4 \\
\hline
\end{tabular}

\begin{tabular}{|c|l|l|c|c|}
28 & $\begin{array}{l}\text { Tribe } \\
\text { from } \\
\text { Maluku }\end{array}$ & $2,203,415$ & 0.93 & 22 \\
\hline 29 & $\begin{array}{l}\text { tribes } \\
\text { from } \\
\text { Papua }\end{array}$ & $2.693,630$ & 1,14 & 19 \\
\hline 30 & China & $2.832,510$ & 1,2 & 18 \\
\hline 31 & $\begin{array}{l}\text { Foreign } \\
\text { ers / } \\
\text { Foreign }\end{array}$ & 162,772 & 0.07 & 31 \\
\hline 32 & Total & $\begin{array}{l}\mathbf{2 3 6 , 7 2 8 ,} \\
\mathbf{3 7 9}\end{array}$ & $\mathbf{1 0 0}$ & \\
\hline
\end{tabular}

There are several factors that led to the appearance of trying to deny the reality of the argument that religion and ethnicity in the Election process that will take place in this area. First, this argument arises because originators did not understand the history and cultural realities in the area in. Secondly, the argument was made an attempt to overcome this emerging resistance to one candidate or candidates of different ethnic backgrounds. Third; showing the issues and the spirit of democratization and strengthening the role of civil society as the base to exclude the issue about SARA (ethnic, religion, race and coomunity group) Fourth, the public awareness that the more intelligent to assess and express their freedom in extending political rights.

Election Medan few years ago, it looks pretty coloring ethnic variations Election process. It is quite evident on Election of Mayor in 2010, which lasted two rounds ..

Composition pair Candidate Mayor and Deputy Mayor who register on election of Mayor and Deputy Mayor of the year 2010 consists of:

1. Couples of Syahrial Anas - Yahya Sumardi (Minang - Javanese)

2. Couples of Sigit Pramono - Nurlisa Ginting (Javanese- Karonese)

3. Couples of Indra Sakti - Delyuzar (Malay Minangkabau)

4. Couples of Bahdin Nurtanjung - Kasim siyo (Mandailings - Javanese)

5. Couples of Joko Susilo - Mirza Hutagalung (Javanes - Toba Batak)

6. Couples of Rahudman - Zulmi Eldin (Batak Mandailing - Malay)

7. Couples of Arif Nasuition - Supratikno (Mandailings - Javanese) 
8. Couples of Maulana Pohan - Ahmad Arief (Mandailiung - Javanese)

9. Couples of Ajib Shah - Binsar Situmorang (Pakistan - Toba Batak)

10. Couples of Sopyan Tan - Nelly Armayanti (Chinese - Minangkabau)

All of the pair of candidates shown any variation of ethnic that exist in Medan city and separate at 21 subdistri ct. This is the event of election where ethnic identy represented from each of the contestant.

\begin{tabular}{|c|c|c|}
\hline \multicolumn{3}{|c|}{$\begin{array}{l}\text { Ethnic Distribution } \\
\text { in North Sumatra Province and Medan City } \\
2010\end{array}$} \\
\hline Ethnic & $\begin{array}{l}\text { Province } \\
\text { of North } \\
\text { Sumatra }\end{array}$ & $\begin{array}{l}\text { city of } \\
\text { Medan }\end{array}$ \\
\hline Angkola-Mandailings & $13: 54$ & 10:16 \\
\hline Karo & $5: 49$ & 4.62 \\
\hline Dairi & 0.78 & $0: 42$ \\
\hline Simelungun & $2: 50$ & 1:41 \\
\hline Shore & $1: 38$ & $1: 10$ \\
\hline Toba & 20.83 & $17: 12$ \\
\hline Nias & 7:01 & $1: 10$ \\
\hline Minangkabau & 2.61 & 7.83 \\
\hline Malay & $4: 42$ & 5.76 \\
\hline Java & 33.47 & 33.19 \\
\hline Chinese & 2.63 & 9:47 \\
\hline Aceh & 0.95 & 2.70 \\
\hline Banjar & 0.99 & $0: 47$ \\
\hline Others & $3: 40$ & 4.65 \\
\hline Total & 100.00 & 100.00 \\
\hline
\end{tabular}

Source: Base on the data from 2010 after organized

\begin{tabular}{|c|c|c|c|c|}
\hline \multicolumn{5}{|c|}{$\begin{array}{l}\text { Javanese, Toba and Angkola-Mandailings at } \\
\text { regency / city in North Sumatra Province } \\
2010\end{array}$} \\
\hline \multirow[b]{2}{*}{$\begin{array}{l}\text { Regency } \\
\text { / City }\end{array}$} & \multicolumn{4}{|c|}{ Ethnic } \\
\hline & Java & Toba & $\begin{array}{r}\text { Angkola- } \\
\text { Mandaili } \\
\text { ngs }\end{array}$ & Other \\
\hline Nias & $0: 07$ & $0: 07$ & $0: 02$ & 99.85 \\
\hline Mandaili & $7: 23$ & $2: 56$ & 78.23 & 11.98 \\
\hline
\end{tabular}

\begin{tabular}{|c|r|r|r|r|}
\hline ng Natal & & & & \\
\hline $\begin{array}{c}\text { South } \\
\text { Tapanuli }\end{array}$ & $6: 56$ & 14.67 & 67.51 & $11: 25$ \\
\hline $\begin{array}{c}\text { Central } \\
\text { Tapanuli }\end{array}$ & $6: 53$ & 56.47 & 4.96 & 32.05 \\
\hline $\begin{array}{c}\text { North } \\
\text { Tapanuli }\end{array}$ & 0.82 & 96.54 & $0: 37$ & $2: 28$ \\
\hline $\begin{array}{c}\text { Toba } \\
\text { Samosir }\end{array}$ & 1.99 & 94.94 & $0: 25$ & 2.82 \\
\hline $\begin{array}{c}\text { Labuhan } \\
\text { Batu }\end{array}$ & 41.55 & $14: 29$ & 25.07 & $19: 09$ \\
\hline Asahan & 58.84 & 20.72 & $5: 42$ & $15: 02$ \\
\hline $\begin{array}{c}\text { Simelun } \\
\text { gun }\end{array}$ & 29.07 & 45.20 & 2.21 & 23.53 \\
\hline Dairi & 1.76 & 72.15 & $12: 43$ & 25.66 \\
\hline Karo & 9.65 & 10.61 & 0.68 & 79.06 \\
\hline $\begin{array}{c}\text { Deli } \\
\text { Serdang }\end{array}$ & 51.81 & 10.82 & 6.68 & 30.68 \\
\hline Langkat & 56.66 & $2: 13$ & $3: 09$ & 38.12 \\
\hline $\begin{array}{c}\text { South } \\
\text { Nias }\end{array}$ & 99.69 & 0.24 & 0.02 & 0.05 \\
\hline $\begin{array}{c}\text { Humban } \\
\text { g } \\
\text { Hasund } \\
\text { utan }\end{array}$ & $0: 33$ & 91.55 & $0: 09$ & $8: 03$ \\
\hline $\begin{array}{c}\text { Pakpak } \\
\text { Bharat }\end{array}$ & $1: 39$ & $13: 37$ & $0: 15$ & 85.09 \\
\hline Samosir & 0.62 & 97.65 & $0: 03$ & 1.70 \\
\hline $\begin{array}{c}\text { Serdang } \\
\text { Bedagai }\end{array}$ & 54.75 & 12.63 & $4: 50$ & 28.12 \\
\hline $\begin{array}{c}\text { Batu } \\
\text { Bara }\end{array}$ & 38.48 & $12: 30$ & $2: 44$ & 46.78 \\
\hline $\begin{array}{c}\text { North } \\
\text { Padang } \\
\text { Lawas }\end{array}$ & 10.62 & $7: 25$ & 75.80 & $6: 33$ \\
\hline $\begin{array}{c}\text { Padang } \\
\text { Lawas }\end{array}$ & 80.02 & 3.15 & 11.49 & 5.34 \\
\hline $\begin{array}{c}\text { South of } \\
\text { Labuhan } \\
\text { Batu }\end{array}$ & 48.80 & $14: 52$ & 29.00 & 7.68 \\
\hline $\begin{array}{c}\text { North } \\
\text { Labuhan } \\
\text { Batu }\end{array}$ & 46.30 & 25.49 & 15.70 & $12: 51$ \\
\hline $\begin{array}{c}\text { Nias } \\
\text { North }\end{array}$ & 99.62 & 0.24 & 0.03 & 0.11 \\
\hline $\begin{array}{c}\text { Nias } \\
\text { West }\end{array}$ & $0: 11$ & $0: 09$ & $0: 01$ & 99.79 \\
\hline Sibolga & 6.81 & 47.39 & $6: 40$ & 39.41 \\
\hline Tanjung & 19.98 & 32.86 & $14: 45$ & 32.72 \\
\hline
\end{tabular}




\begin{tabular}{|c|r|r|r|r|}
\hline Balai & & & & \\
\hline Siantar & 25.45 & 45.95 & $6: 53$ & $22: 07$ \\
\hline $\begin{array}{c}\text { Tebing } \\
\text { Tinggi }\end{array}$ & 40.65 & 13.74 & $11: 16$ & 34.45 \\
\hline Medan & 33.19 & 17.12 & 10.16 & 39.52 \\
\hline Binjai & 52.09 & 5.87 & $9: 11$ & 32.93 \\
\hline $\begin{array}{c}\text { Padang } \\
\text { Sidempu } \\
\text { an }\end{array}$ & 11.31 & 14.48 & 64.91 & 9.29 \\
\hline $\begin{array}{c}\text { Gunung } \\
\text { Sitoli }\end{array}$ & 1.03 & 1.15 & 0.38 & 97.43 \\
\hline total & $\mathbf{3 3 . 4 7}$ & $\mathbf{2 0 . 8 3}$ & $\mathbf{1 3 : 5 4}$ & $\mathbf{3 2 . 1 6}$ \\
\hline
\end{tabular}

Soure: Data from BPS after oragnized 2010

\section{METHODOLOGY}

This research will be done with qualitative method through analysis and interpretation of the data that has been resulted from Recapitulation of the vote at the election of 2010. Comparison with the ethnic composition on each subdistrict, running depth interview with the informants by using purposive and snowball sampling. ${ }^{3}$

\section{RESULT AND DISCUSSION}

The success of the couple Rahudman and Eldin won the General Election of Medan in 2010 were actually not only due to variations in ethnic composition alone, but also by factors of support in terms of religion (in this case Islam) that favor both spouses postscript both are religious Islam. ${ }^{4}$ While the couple of Sopyan Tan - Nelly lost support from Moslem people. This is the reality that can not be denied. Voters were originally rational becomes irrational when faced with two choices on issues related to faith.

In the first round; where the fight among the 10 candidates have had to include couples with ethnic background consists of: Mandailings, Arabic, Malay, Javanese, Karo, China, Minangkabau. Furthermore, in the second round, there are two candidates who emerged as the winner and is entitled to enter the second round. Both candidates have each represent variations

[3] 3 Spradly, James, "Ethnographic Methods" Tiara discourse, Jogjakarat, 1997; Fetterman "Ehnography Step by Step" Vol.17, Vanederbit University, Nashville

[4] ${ }^{4}$ Depth interview with Nelly Armayanti, 27 November 2017 that represent the ethnic composition: Mandailings, Malay, Chinese and Minangkabau. Variations of this ethnic composition is interesting to observe because each represents a different ethnic, ethnic variation Fourth then join and compete with each other. Finally the candidate pair number 6 which Rahudman Eldin is a blend of Malay ethnic Batak Mandailing and Medan won the General Election; while the pair number 10 , Sofyan Tan- Nelly representing ethnic Chinese and Minangkabau.

\section{CONCLUSION}

The regional head election 2010 in Medan city has been done in two rounds. Round I, Rahudman- Eldin pair performed well with a vote of $51.72 \%$, Followed by the couple Sopyan Nelly in second with $48.28 \%$ of votes. In the second round, Rahudman Eldin succeeded in getting $65.88 \%$ while the couple Sopyan Tan Nelly only get votes as much as $34.12 \%$.

At the first round, Rahudman Eldin pair succed to get a vote of support from 10 subdistrict with a total of $51.72 \%$, meanwhile, Sopyan Nelly get support from 11 Subdistrict with totally $48.28 \%$

At the second round, Rahudman Eldin get support of votes from 18 subdistrict in Medan city with a total of $65.88 \%$, and Sopyan Tan Nelly get support from 3 Subdistrict with a total of $34.12 \%$.

Based on the reality above, there was clear if ethnic contestation in the election of majors and vice majors in Medan city in 2010 not only shown by the ethnic factor but Also religion factor. But according to Nelly5, there is key factor that have made her lost in this contestattion. Most people in Medan still have orientation to elect the leader based on the ethnic and religious. But when they should be to elect based on ethnic or religion, people tend to choose based on the religion.

\section{ACKNOWLEDGMENT}

I would like to thank to the graduate program of Medan State University, especially the lecturers of Post-Graduate of Social Anthropology, who provide Reviews their time to

\footnotetext{
5 Interview with Nelly Armayanti, the vice major candidate on the Election 2010, 27 November 2017
} 
give advice during consultation and discussion to complete this paperr.

\section{REFERENCES}

[1] Aminah, Siti, Kuasa Negara pada Ranah Politik Lokal, Prenadamedia Group, Jakarta, 2014

[2] Barth, Frederick, "Kelompok Etnik dan Batasannya, UI Press, Jakarat, 1988

[3] Balandier. Georges, Antropologi Politik, PT. Raja Grafindo Persada, Jakarta, 1996

[4] Fetterman, David M, Ethnography Step by Step, third edition, Applied Research Methode Series, Volume 17, Peabody Ccollege, Vanederbit University, Nashville

[5] Geertz, Clifford, "Mojokuto: Dinamika Sosial Sebuah Kota di Jawa", Rajawali Pers, Jakarta, 1986
[6] Marijan, Kacung, "Ilmu Politik dalam Paradigma Abad 21" Jilid 1 (ed) John T. Ishiyama dan Marijke Breuning, Kencana Prenada Media Gorup, Jakarta, 2013

[7] Pelly, Usman , Urbanisasi dan Adaptasi: Peranan Misi Budaya Minangkabau dan Mandailing, LP3ES, Jakarta, 1994

[8] Pelly, Usman "Etnisitas : Dalam Politik Multikultural, Buku III, Casamesra Publisher, Medan, 2016,

[9] Spradely, James, "Metode Etnografi" Tiara wacana, Jogjakarta, 1997

[10] Irsan, Hubungan Etnik Dan Kontestasi Politik Dalam Pemekaran Daerah : Kajian Kes Tentangan Elit Tempatan Di Pringsewu, Provinsi Lampung, Indonesia, thesis untuk memenuhi ijajah Doktor Falsafah, Universiti Sains Malaysia , 2015

[11] Stasticial Bureau, 2010

[12] Recapitulation result of Regional Head Election year 2010 in Medan City, KPU Medan, 2010

[13] Http://akhirmh.blogspot.co.id, 